\title{
The Dynamics of Paddy Land Legal Policy in Indonesia
}

\author{
Sri Wahyu Handayani ${ }^{11}$ Siti Kunarti $^{1}$, and Supriyanto ${ }^{1}$ \\ ${ }^{1}$ Faculty of Law, Jenderal Soedirman University, Purwokerto, Indonesia
}

\begin{abstract}
This research is conducted to describe the history of paddy land legal policy in Indonesia. Indonesia is an agrarian country which has ever received an award as rice self-sufficiency country in 1984. Nevertheless, now Indonesia becomes rice importer as paddy land decreases. Thus, it needs to be examined from dynamics of legal policy protection side. This research is divided into three periods, the appearance of Basic Agrarian Law in 1960, the New Order period until 1999, and Reformation period until 2017. The used method is historical method. This research also investigates several problems that arise from the implementation of paddy land legal policy in Indonesia.
\end{abstract}

\section{Introduction and literature Review}

Indonesia has received an award from Food and Agriculture Organization (FAO)in Rome, Italy 1984 due to rice self-sufficiency. Yet, self-sufficiency era has ended since now Indonesia imports rice from other countries such as China, Thailand, and Vietnam in which they have learned rice farming from Indonesia. The other issue is the amount of rice that cannot be expected as before. Rice is considered as inelastic commodity where the number of request may be high but the number of offer does not increase, even it decreases. Indonesia is the third world rice producer with the amount of production 75,6 million ton rice. Nevertheless, to accomplish domestic need, Indonesia must import rice from another country in amount of 1 million ton [1]. Indonesia is the third world rice producer with the amount of production 75,6million ton rice. Nevertheless, to accomplish domestic need, Indonesia must import rice from another country in amount of 1 million ton [2].

State's role is needed to realize food sovereignty especially rice. Indonesia has the new Food Law to replace Law Number 7 Year 1996 which has applied for 16 years. It is Law Number 18 Year 2012 about Food. The new Law is aimed to achieve three things which are food sovereignty, food independency, and food security. Food sovereignty aspect is included as a consequence that Indonesia has ratified International Covenant on economic, social, and cultural rights through Law Number 11 Year 2005 (usually abbreviated into ECOSOC Rights) [3]. Indonesia has many agenda on food sovereignty

\footnotetext{
${ }^{1}$ Corresponding email : ayufh27@gmail.com
} 
particularly on agrarian reform. Since only food sovereignty which based on genuine agrarian reform that will be our weapon to face the future multi crisis. "Food sovereignty is the only way to effectively protect national food economy from external stress in form of dumping, stockpiling, and speculation" [4].

One of the causes that encourage Indonesia to import rice is paddy land digression. The lowering area of agriculture is one of the digression causes. Also there is a tendency of fast land conversion from agricultural land into non-agricultural land. From 1981 until 1999 there are land conversion in Java in amount of 1 million hectares and 0.62 million hectares outside Java [5]. Therefore, this paper will explain the history of paddy land protection in Indonesia in 1960 until 2017.

\section{Objective of the study}

This research is conducted to describe the history of paddy land legal policy in Indonesia. This research is divided into three periods, the appearance of Basic Agrarian Law in 1960, the New Order period until 1999, and Reformation period until 2017. This research aims to investigate several problems that arise from the implementation of paddy land legal policy in Indonesia.

\section{Methodology}

To describe the history of paddy land legal policy in Indonesia, this research uses historical method through literature review on books, regulations, and previous researches. This research also uses the data that collected by official government agency and completed by interview with several staffs of ministry office that handle paddy land conversion control.

\section{Discussion}

\subsection{The Birth of Basic Agrarian Law in 1960}

The independency of Indonesia gave a new spirit to make people live in prosperity by constitution's message in Article 33 Constitution Law 1945 Paragraph 3 that state earth and water is organized by State and shall be used to the greatest benefit of the people. It was in line with land reform spirit that issued after Basic Agrarian Law ratification and the birth of Law Number 56 Government Regulation in Lieu of Law Year 1960 on Stipulation of the Size of Agricultural Land. This law determined the authority limitation on minimum and maximum area by differentiating paddy land and dry land based upon population density. The maximum area of authority in not densely populated area was 15 hectares and 5 hectares in densely populated area. For dry land, maximum authority in not densely populated area was 20 hectares and 5 hectares addition for special condition with Agrarian Ministry permission. This Law ensured that Government would make an effort to make each farmer's family had at least 2 hectares land. A farmer who had a land less than 2 hectares was called small farmer. This law prohibited a farmer to transfer his right upon his land that caused authority less than 2 hectares, except for inheritance. Government also obliged farmers to merge their less than 2 hectares land. There was punishment for violating maximum authority of agricultural land in which imprisoned for three months and or fine in amount of Rp. 10.000,00. This fine nominal was not relevant with today's nominal. Thus it needed to be reviewed. This Law also ensured a regulation about 
limitation of land authority and settlement area that would be arranged by government regulation but had not been published until now.

As implementation of Law Number 56 Government Regulation in Lieu of Law Year 1960 on Stipulation of the Size of Agricultural Land, there was Government Regulation Number 224 Year 1961 on Implementation of Land Distribution and Indemnity Provision that later changed to Government Regulation Number 41 Year 1964. Basically, this regulation prohibited absentee ownership of agricultural land. Absentee comes from the word "absent" which means no presence. This regulation also prohibited land authority outside the sub-district of land's location. The purpose of these prohibitions was to make the result or product of the land shall be used by the people around the land's location [6].

\subsection{The New Order Period until 1999}

New order period planned Green Revolution as the solution to face rice deficit. One of the problems in New Order period was the amount of food production that was not balance with the increasing number of population. Hence, New Order government included Green Revolution in Pelita program. Green Revolution concept in Indonesia was known as mass guidance. It is a national program which aimed to increase food production especially rice sufficiency. This movement succeeded in bringing Indonesia to rice self-sufficiency until 1984. Indonesia received an award from FAO and Green Revolution was implemented by extensification and intensification. Extensification was done by expanding agricultural land in form of paddy land or dry land to produce foodstuff especially rice. Intensification was done by optimizing paddy land by using quality seeds, fertilizer, well irrigation, pesticides, insecticides, and fungicides. Also by holding socialization, good transportation and communication, also good marketing. Nevertheless, Green Revolution was not capable to make Indonesia as stable rice self-sufficiency state. It just lasted for five years from 1984 until 1989.

The success of Green Revolution was apparent since many negative effects emerged from this movement such as land pollution that caused damage to fertile land, pesticide resistance disease, fertilizer commercialization with unsuitable price and there was no explanation on negative effect in using fertilizer continuously. According to Irsal Las, one of the failure factors of Green Revolution was too rely on irrigated paddy land as farmer media and gave less attention to suboptimal land [7]. In New Order period, development policy was concerned on national economic development. It was done by raising the development of industrial sector including agricultural industry. To achieve them, it needed to stimulate investment growth especially big sector investment. Along with the purpose, big scale business had been developed (for instance big scale private plantation). Different from Old Order period that concerned on land reform, New Order development policy was more directed to liberalization and land reform program was no longer a concern [8].

Urban sector development had increased the need of land for industry, settlement, infrastructure, and agricultural land conversion. Industrial and settlement development prefer an area which had good infrastructure. It caused industry and settlement locations were placed around area of a big city and fertile agricultural land. The level of fertile land conversion into non-agricultural land had reached the disturbance stage which affected national food production in short term and medium term. The increasing number of agricultural business actor who owned a land and the actor outside agricultural sector had made accumulation of land ownership by particular group (stratification). In other side, it increased the number of farmer with no land, small farmer, and the ownership of land by the people outside the region. 


\subsection{Reformation Period}

New Order period was ended by Reformation movement in 1998 through leadership change. This period tried to even up the development through regional autonomy. Regional autonomy had started in 2002. In this period, agricultural land conversion was increasing as an effort to increase investment in non-agricultural sector for Regional Autonomy's Original Income. However, there were central government policies that contributed to agricultural land conversion such as highway construction. In according to Central Bureau of Statistic (2001) stated that paddy land area in Indonesia in 1993 was around 8.500.000 ha. Then in 2000 (7 years), the land had been decreased and became 7.790 .000 ha or the reduction was 710.000 ha or each year Indonesian paddy land was decreased in amount of 59,167 ha [9].

According to "the data that agreed by various parties", the average amount of land conversion into non-agricultural land was around 110 thousand hectare each year. It was included as non-agricultural or other use except for paddy land. In Java (the area where technical and non-technical irrigated paddy land located) most of land conversion turned into non-agricultural land (58,7\% became settlement, $21,8 \%$ became industrial area, office, shop, and etc). Outside Java, the proportion of land conversion into settlement was around $16,1 \%$, non-agricultural land in amount of 49\% (Public Works Department 2008). If the paradigm did not change in controlling paddy land conversion (business as usual), there were $42 \%$ paddy land that would be converted in spatial planning. In Java and Bali (where the lands were so fertile but decreased) the land that would be converted hit $49 \%$ [10].

Government immediately took a rescue action by publishing Law Number 41 Year 2009 on Protection of Agricultural Land Sustainable Food (PLP2B). Ahmad Makky Arrozi suggested that there were 7 critical knots in implementing Law Number 41 Year 2009 to support food security which involve: (1) Regional Regulation support; (2) comprehension of agricultural land resources characteristic; (3) land type identification based on irrigation type and land class; (4) farmer land authority structure; (5) uncontrolled land conversion; (6) division and fragmentation of land; and (7) the importance of developing information centre [11].

The birth of Law Number 41 Year 2009 about PLP2B was expected to be a foundation for national agricultural sector development. Central and Regional government were demanded to ensure the availability and protection of agricultural land, also the sustainability of agricultural reserve inside or outside agricultural region. The assurance should realize national food independency, food security, and food sovereignty. The implementation of Law Number 41 Year 2009 was done by firstly made a plan and determined the sustainable agricultural land inside or outside agricultural region. The critical point of Law Number 41 Year 2009 was in Article 44 that arranged sustainable agricultural land conversion. In the Article, land conversion was basically prohibited except for public interest with several tight requirements such as agricultural land substitution. There was punishment if the requirements of land conversion were not fulfilled as it was explained in Article 72 until 74 of the law. Therefore, in arranging regional regulation about PLP2B, several aspects need to be concerned and many institutes must be involved. Technically, it was arranged in Government Regulation Number 1 Year 2011 on PLP2B.This Protection of Agricultural Land Sustainable Food was in line with Law Number 26 Year 2007 about spatial planning. This law stipulates that Spatial Planning is a system process of spatial planning of spatial use and its control. Article 48 Paragraph 2 Law of Spatial Planning arrange about Rural Area Spatial Planning that directed to be eternal sustainable agricultural land area. 


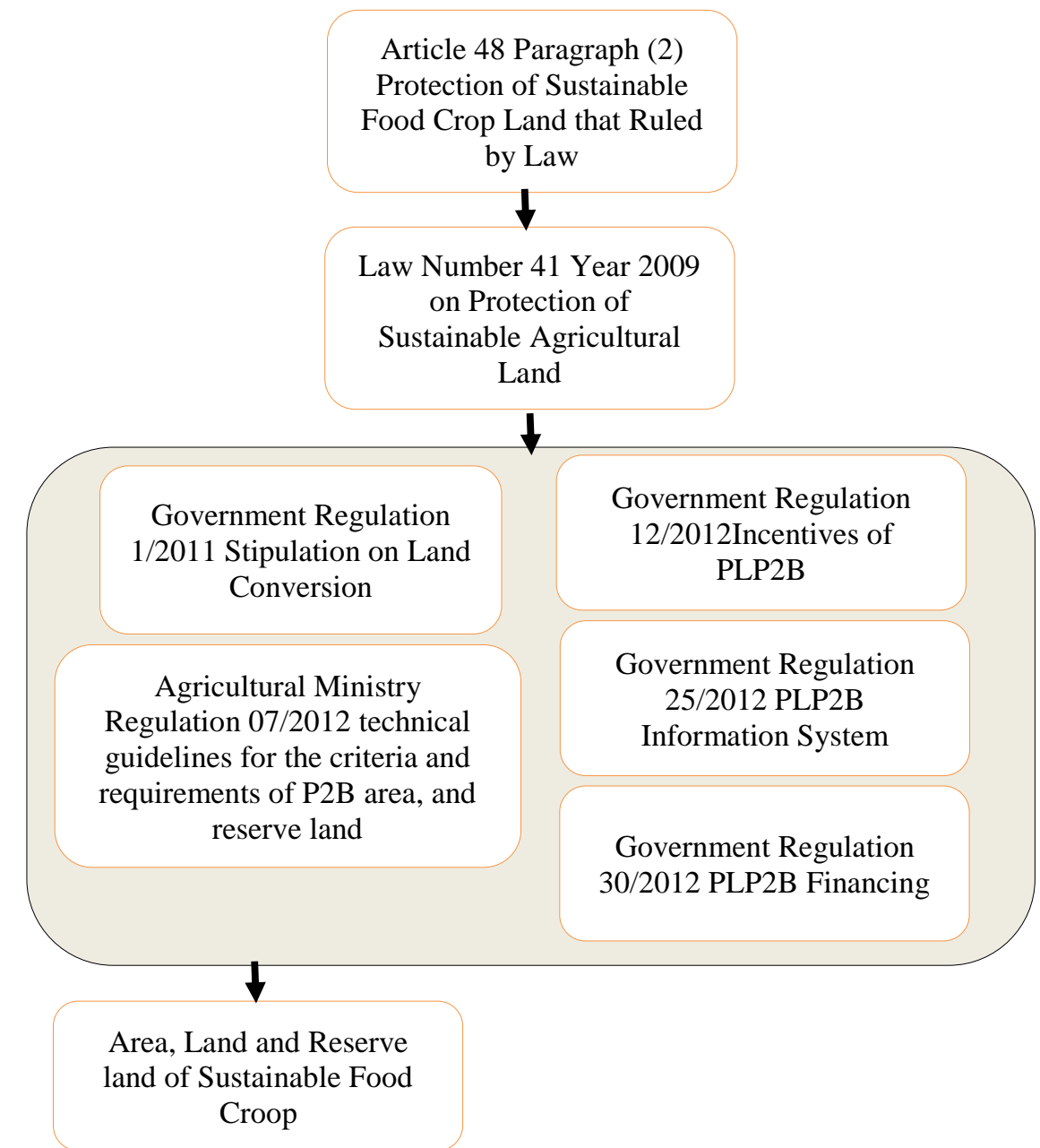

Fig 1. Harmonization Scheme of Spatial Planning and Protection of Agricultural Land Sustainable Food

Various regulations have been made to prevent agricultural land conversion into nonagricultural conversion. However, agricultural land conversion continuously to happen along with non-agricultural sector role in national economic development. In example, establishment of cross Java highway that potentially decrease agricultural land for the establishment or settlement around the highway. Regency/City government may use the exist regulation to protect the land. Nevertheless, the regulations to prevent land conversion are not quite effective since there is no law enforcement. The problems that arise with the enactment of Law 41/2009 are, there is no substitution for land conversion, alternative land for food crop agriculture does not last long if the owner convert the land into nonagricultural land, recent regulation about protection of agricultural land sustainable food that gives punishment to local officials is considered to harm them due to inconsistent implementation of others regulation. Also, there is no incentive for a region that maintains their area as agricultural producer, especially food crop, since original regional revenue is more profitable when the region is non-agricultural land area.

Moreover, the problem arises from incentive policy within agricultural land sustainable food (LP2B). Local government that publishes LP2B must provide funds as 
incentives for LP2B regions. This incentive funds have not budgeted by central government. In consequences, the funds are taken from regional income and causes local government to object. Even the fertilizer subsidy from central government is not helping to prevent land conversion. It can be seen from 508 Regency/city, only 225 (44,29\%) that applied Regional Regulation on LP2B and from that regulation only 0,24\% or around 19.171 hectares land that geospatially determined as LP2B area [12].

\section{Conclusion}

Paddy land as rice field media since Agrarian Reform 1960 has gotten government's concern. Government has published many regulations and policies to maintain paddy land. Nevertheless, agricultural land conversion is difficult to control from personal or public sector such as infrastructure establishment. The regulations are not comprehensive especially on incentive or disincentive and its cost. It happens related to authority division between central and local government in regional autonomy. Therefore, it needs local concern in maintaining paddy land in their own region but still pay attention to their Original Income. The concern can be realized from publication of complete regulations about LP2B.

\section{References}

1. D. A. Kumalasari, Rice Self-Sufficiency Policy Scenario in Indonesia Jurnal Habitat XXIV (2013)

2. The amount of Production, Export, Import from FAO publication (Food and Agriculture Organization) of the United Nations, Rice Market Monitor, Volume XVIII Issue No. 2, (2015)

3. Syahyuti et.al, "Food Sovereignty as the Basis to Realize National Food Security" Agro Economic Research Forum 33 No 2 (2015).

4. Rosset, P. 2011. Food sovereignty and alternative paradigms to confront land grabbing and the food and climate crises Development 54 (1), p. 21-30.

5. Prasetya,"Indonesia Negara Penghasil Pangan yang Masih Impor Bahan Pangan" https://www.kompasiana.com/ferrynang/550a1d6e8133117f1cb1e72d/indonesia-negarapenghasil-pangan-yang-masih-impor-bahan-pangan, accessed on August 1, 2018.

6. B. Harsono, Ind. Agr. Law: The History of Basic Law Formation, Content, and Its Implementation. Revision Edition. 10, 385. (Jakarta, Djambatan, 2005)

7. I. Las, "Sustainable Green Revolution for Future Food Security." Sinar Tani Tabloid, January 14, (2009)

8. M. Rachmat and C. Muslim, Dynamics of Land Mastery and Agricultural Work Institutions. Land Mastery and Fragmentation. Retrieved from http://www.litbang.pertanian.go.id/buku/konversi-fragmentasi-lahan/BAB-III-2.pdf on August 5, 2018

9. Indonesia Central Bureau of Statistic (2001).

10. Winoto J. 2005. Policy of Agricutural Land Conversion and Its Implementation. Oneday seminar Controlling Land Conversion and Eternal Agricultural Land, Jakarta, December 13, 2005

11. A. M. Arrozi and Saptana. Implementation of Law on the Protection of Agricultural Land Sustainable Food (PLP2B) in Supporting Food Security in Banten Province.http://pse.litbang.pertanian.go.id/ind/pdffiles/PROS2013_D3_Ahmad\%20Mak ky.pdf on August 5, 2018. 
12. The data of Agrarian Ministry and Spatial Planning/ National Land Agency 2017 